\title{
BIOLOGICAL ACTIVITIES AND PHYTOCHEMICAL SCREENING OF LEAF EXTRACTS FROM Zanthoxylum caribaeum L. (Rutaceae)
}

\author{
ATIVIDADES BIOLÓGICAS E PROSPECÇÃO FITOQUIMICA DE EXTRATOS \\ VEGETAIS DAS FOLHAS DE Zanthoxylum caribaeum L. (Rutaceae)
}

\author{
Juliete Gomes de Lara de SOUZA ${ }^{1}$; Fabiana Gisele da Silva PINTO' ${ }^{1 *}$ \\ Adrieli Gorlin TOLEDO ${ }^{1}$; Luis Francisco Angeli ALVES ${ }^{1 * *}$; Dejane Santos ALVES ${ }^{2}$ \\ 1. Program of Conservation and Management of Natural Resources, Biotechnology Laboratory, West of Paraná State University - \\ UNIOESTE, Cascavel, Paraná, Brazil; 2. Federal Technological University of Paraná - UTFPR), Santa Helena, Paraná, Brazil. \\ Corresponding author: * fabiana.pinto@unioeste.br; ** Research Productivity Scholar, CNPq
}

\begin{abstract}
The Brazilian flora is known for its vast biodiversity; however, many species have been still little studied regarding to their chemical composition and biological potential. Thus, this study aimed to determine the antimicrobial, antioxidant and acaricidal activity of the extracts of leaves of Zanthoxylum caribaeum L. In addition, phytochemical screening of these extracts was carried out to determine the main classes of secondary metabolites present in Z. caribaeum. Using the Z. caribaeum leaves, aqueous and organic extracts were obtained using the following solvents (ethanol, methanol, hexane, acetone, dichloromethane and ethyl acetate). The antimicrobial activity of extracts was determined by broth microdilution method, and to detect antioxidant activity the method of capturing the free radical 2,2-diphenyl-1-picryl hydrazyl (DPPH) was used. The acaricidal activity of the extracts was tested on Dermanyssus gallinae (De Geer) (Acari: Dermanissidae). Ethanolic and methanolic extracts presented antimicrobial activity for most of the bacterial strains tested, as well as for yeast Candida albicans. The ethanolic extract presented high free radical sequestration potential $(71.2 \%)$ and antioxidant capacity (the lowest $\mathrm{IC}_{50}$ value $-24.39 \mu \mathrm{g} \mathrm{mL} \mathrm{m}^{-1}$ ). The crude extracts obtained with methanol and acetone were the most promising. In general, phytochemical screening indicated the presence of steroids, flavanones, flavones, flavonols, saponins, tannins, triterpenoids and xanthones.
\end{abstract}

KEYWORDS: Antimicrobial activity. Antioxidant activity. Acaricidal activity. Poultry red mite. Salmonella enterica.

\section{INTRODUCTION}

Brazil is home to one of the richest floras in the world, with about $10 \%$ of the world's total species (MUGGE et al., 2016). Brazilian megadiversity represents an invaluable source of new substances, derived from the secondary metabolism of plants, which may present antimicrobial (COSTA et al., 2010; SILVA et al., 2017), antioxidant (PEREIRA et al., 2016; SANTI et al., 2017) and acaricide activity (FERRAZ et al., 2017). In addition, many products marketed by the pharmaceutical industry, originate from plants, being possible to mention digoxin from Digitalis spp. (Plantaginaceae); vincristine and vinblastine from Catharanthus roseus (L.) G. Don (Apocynaceae); atropine of Atropa belladonna L. (Solanaceae), among others (RATES, 2001).

Secondary plant metabolites may also serve as a model molecule for pesticides' synthesis, such as pyrethroids synthesized using pyrethrins, extracted from chrysanthemum flowers Tanacetum cinerariifolium (Trevir.) Sch. Bip (Asteraceae)
(PALMQUIST; SALATAS; FAIRBROTHER, 2012) and are widely used as pesticides.

Among the numerous botanical families with recognized biological activities, the Rutaceae family, whose representatives are known for the synthesis of alkaloids, coumarins, lignans, flavonoids and limonoids (SUPABPHOL; TANGJITJAREONKUN, 2014; TUNDIS; LOIZZO; MENICHINI, 2014) are noteworthy. Many substances belonging to these chemical classes present antioxidant properties (Baj et al., 2017) and are toxic to microorganisms (ADAMSKA-SZEWCZYK; GLOWNIAK; BAJ, 2016; ZHANG et al., 2017) and arthropods (GREGER, 2017; LV et al., 2015).

In this context, the species Zanthoxylum caribaeum L. (Rutaceae), despite the scarcity of studies in the literature, is notable for the presence of antimicrobial activity of its extracts and its essential oil against Salmonella serotypes of poultry origin (SOUZA et al., 2017), as well as for Staphylococcus aureus and Escherichia coli (ORDAZ PICHARDO et al., 2014). Its toxicity as 
an acaricide for Rhipicephalus microplus (Canestrini) (Acari: Ixodidae) (NOGUEIRA et al., 2014a) and as an insecticide for Rhodnius prolixus (Stal) (Hemiptera: Reduviidae) (NOGUEIRA et al., 2014b) has also been confirmed.

This specie of the Rutaceae family is widely distributed in the neotropical region, occurring in all Brazilian states (PIRANI, 2015). In addition, $Z$. caribaeum presents antimalarial and antirheumatic properties, and it is also used in the popular medicine in the treatment of several diseases (FERREIRA et al., 2007; SCHNEE, 1984).

Thus, considering the biological activities of plants' secondary metabolites and the scarcity of $Z$. caribaeum information, the present study aimed to evaluate the antimicrobial, antioxidant and acaricide activity of secondary metabolites of $Z$. caribaeum leaf extracts. In addition, the main classes of secondary metabolites presented in $Z$. caribaeum leaves extracts were investigated by phytochemical screening.

\section{MATERIAL AND METHODS}

\section{Botanical material}

The leaves of $Z$. caribaeum were collected from January to April 2015 in the ecological park Paulo Gorski, Cascavel, PR, Brazil (245'니 "S, $\left.53^{\circ} 26^{\prime} 2^{\prime \prime} \mathrm{W}\right)$. An exsiccate of the plant was deposited in State University of the West of Paraná Herbarium (UNOP) (voucher number UNOP 1849). The leaves were dried and ground following the assumptions of Weber et al. (2014), originating the vegetal powder used to obtain the extracts.

\section{Aqueous extract}

Initially, distilled water $(\mathrm{Aq})(100 \mathrm{~mL})$ was added to the dry botanical material (40 g), the mixture was maintained on a rotary incubator (220 rpm, $24 \mathrm{~h}, 22^{\circ} \mathrm{C}$ ). After this period, the mixture was filtered using Whatman $n^{\circ} 1$ filter paper and centrifuged at $5000 \mathrm{rpm}$ for 15 minutes. The supernatant was collected giving rise to the aqueous extract, it was maintained at a temperature of $4^{\circ} \mathrm{C}$ until used in the bioassays.

\section{Organic solvent extracts}

Organic extracts were obtained according to the assumptions of Pandini et al. (2015), with modifications. Ethanol $(\mathrm{EtOH})$, methanol $(\mathrm{MeOH})$, hexane (Hex), acetone (AcO), dichloromethane $\left(\mathrm{CH}_{2} \mathrm{Cl}_{2}\right)$ and ethyl acetate (EtOAc) were used as solvents. The vegetable powder $(40 \mathrm{~g})$ was subjected to extraction with the solvents $(100 \mathrm{~mL})$ and followed the same procedure as with the aqueous extract, then the supernatant was collected and the solvent was removed on a rotary evaporator, yielding the crude soluble extracts in $\mathrm{EtOH}, \mathrm{MeOH}$, $\mathrm{Hex}, \mathrm{AcO}, \mathrm{CH}_{2} \mathrm{Cl}_{2}$ and AcOEt. The extracts were kept in a freezer at $4^{\circ} \mathrm{C}$.

\section{Phytochemical screening}

Aqueous and organic solvent extracts of $Z$. caribauem were tested for the presence of alkaloids, anthocyanins, anthocyanins, aurones, chalcones, coumarins, steroids, flavanones, flavones, flavonols, saponins, condensed tannins, triterpenoids and xanthones, according to a methodology described by Matos (1997). The qualitative results were expressed as presence/positive reaction $(+)$ weakly positive or strong positive reaction $(++)$ with higher intensity (more concentrated reactions), and absence /negative reaction (-) of phytochemicals.

\section{Microorganisms used and inoculum preparation}

The strains of the collections American Type Culture Colletion (ATCC) and "Cefar Diagnóstica" (CCCD), were used to evaluate the antimicrobial potential of $Z$. caribaeum, six of the strains were Gram-negative, Salmonella enterica subspecies enterica sorovar Enteritidis (ATCC 13076), Salmonella enterica subspecies enterica sorovar Typhimurium (ATCC 14028), Escherichia coli (ATCC 25922), Pseudomonas aeruginosa (ATCC 27853), Proteus mirabilis (ATCC 25933) and Klebsiella pneumoniae (ATCC 13883) and four strains were Gram-positive: Staphylococcus aureus (ATCC 25923), Staphylococcus epidermidis (ATCC 12228), Enterococcus faecalis (ATCC 19433) and Bacillus subtilis subspecies spizizenii (CCCD-B005) and the yeast Candida albicans (ATCC 10231). In addition, three serotypes of Salmonella enterica subspecies enterica of the highest occurrence in the western region of Paraná, Brazil (SCUR et al., 2014), were isolated from chicken broilers from the region: Heildelberg, Gallinarum and Newport yielded by Veterinary Laboratory, MercoLab from Cascavel, Paraná, Brazil (www.mercolab.com.br).

The microorganisms were recovered in Brain Heart Infusion (BHI) broth and incubated for 24 hours at $36 \pm 0.1^{\circ} \mathrm{C}$ in a B.O.D. After that, the strains were harvested in Muller Hinton Agar $(\mathrm{MH})$ culture media and incubated for $24 \mathrm{~h}$ at $36 \pm 0.1^{\circ} \mathrm{C}$ in a B.O.D. To standardize the inoculum, the strains were diluted in saline solution $(0.85 \%)$ resulting in the final concentration of $1 \times 10^{5} \mathrm{CFU} \mathrm{mL}^{-1}$ for

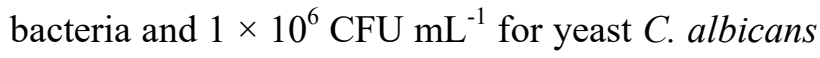
(Mcfarland scale). 


\section{Antimicrobial activity}

Aqueous and organic solvent extracts were used to determine the Minimum Inhibitory Concentration (MIC) according to the microdilution method of Pandini et al. (2015), with modifications. For the bioassay with the bacteria, the plant extracts were solubilized in methyl alcohol and MuellerHinton broth $(\mathrm{MH})$. Whereas for $C$. albicans Roswell Park Memorial Institute broth (RPMI1640) was used. Concentrations ranging from 200 to $0.09 \mathrm{mg} \mathrm{mL}^{-1}$ of each extract were obtained. Then the inocula $(10 \mu \mathrm{L})$ were added to each well, and the plates were incubated for 18 to $24 \mathrm{~h}$ at $36 \pm 0.1{ }^{\circ} \mathrm{C}$. After that time, $0.5 \%$ triphenyltetrazolium chloride (TTC) $(10 \mu \mathrm{L})$ was added and the plates were again incubated for $3 \mathrm{~h}$ at $36 \pm 0.1^{\circ} \mathrm{C}$. Presence of red staining was indicative of microorganismal growth. As a positive control, the antibiotics gentamicin $\left(200 \mathrm{mg} \mathrm{mL}^{-1}\right)$ and nystatin $\left(200 \mathrm{mg} \mathrm{mL}^{-1}\right)$ were added to the culture media MH and RPMI, respectively. Microbial wells were reserved for control of broth sterility (MH/RPMI only), bacterial growth (bacterial suspension and MH/RPMI), reference antimicrobial action (bacterial suspension, MH/RPMI and gentamicin $200 \mathrm{mg} \mathrm{mL} \mathrm{m}^{-1}$ ) and solvent (bacterial suspension, MH/RPMI and methanol).

According to the method proposed by Weber et al. (2014) with modifications, prior to the addition of TTC in all wells, as described above, aliquots $(2 \mu \mathrm{L})$ were withdrawn from each well containing culture medium and the microorganisms, which was inoculated onto the surface of $\mathrm{MH}$ agar. The plates were incubated for $24 \mathrm{~h}$ at $36 \pm 0.1^{\circ} \mathrm{C}$ and after this time the Minimum Bactericidal Concentration (MBC) and Minimum Fungicidal Concentration (MFC) was defined as the lowest of the plant extract capable of causing the inoculum death. The MIC and the MBC of the extracts were classified according to the methodology of (PANDINI et al., 2015), the activity was considered high $\left(<12.5 \mathrm{mg} \mathrm{mL}^{-1}\right)$, moderate $\left(12.5\right.$ to $25 \mathrm{mg} \mathrm{mL}^{-}$ $\left.{ }^{1}\right)$, low (50 to $100 \mathrm{mg} \mathrm{mL}^{-1}$ ) and very low $(>100 \mathrm{mg}$ $\left.\mathrm{mL}^{-1}\right)$.

\section{Antioxidant activity}

Aqueous and organic solvent extracts had the antioxidant activity evaluated according to the free radical reduction method 2,2-diphenyl-1-picryl hydrazyl (DPPH) (PANDINI et al., 2015). For that, alíquots of aqueous and organic solvent extracts $(0,1$ $\mathrm{mL})$ were solubilized in MeOH PA (200 $\left.\mathrm{mg} \mathrm{mL}^{-1}\right)$ and added the methanolic solution of DPPH $(0,2$ $\mathrm{mM})(3,9 \mathrm{~mL})$. The absorbance of the samples was read at $515 \mathrm{~nm}$ using the FEMTO spectrophotometer, 700 Plus. As negative control methyl alcohol $(50 \%)$, acetone $(70 \%)$ and water $(2$ : 2: 1) were used, the synthetic antioxidant Butylhydroxytoluene (BHT) was used as a positive control. The ability to eliminate DPPH (\% antioxidant activity) was calculated using the following equation: $I \%=\left[\frac{\left(A_{0}-A_{1}\right)}{A_{1}}\right] \times 100$, where $A_{0}$ is the absorbance of the control, $A_{1}$ is the absorbance of sample and $I \%$ is the percentage of antioxidant activity. The $\mathrm{IC}_{50}$ (amount of antioxidant substance needed to reduce the initial concentration of DPPH by $50 \%$ ) was calculated based on the equation of the straight line obtained from the calibration curve.

\section{Acaricidal activity}

The poultry red mite Dermanyssus gallinae (De Geer) (Acari: Dermanyssidae) was collected in a commercial poultry layer house, without reports of the use of sanitary products, located in the city of Matelândia / PR, Brazil $\left(25^{\circ} 26^{\prime} 8.15^{\circ} \mathrm{S}\right.$, $\left.54^{\circ} 04^{\prime} 39.5^{\circ} \mathrm{W}\right)$. Engorged females were selected (FLECHTMANN, 1985) and packed in glass tubes closed with voile tissue. The mites were maintained for acclimation for $24 \mathrm{~h}$ under controlled conditions ( $25 \pm 1{ }^{\circ} \mathrm{C}, 70 \%$ U.R. and $14 \mathrm{~h}$ photophase), the bioassays were also conducted under the same conditions.

The trials were conducted in a completely randomized design, with five replicates per treatment, and the experimental plot consisted of 25 mites. The treatments consisted of plant extracts at the concentrations of $125,250,500,750$ and 1000 $\mathrm{mg} \mathrm{mL} \mathrm{m}^{-1}$. Organic solvent extracts were solubilized in $\mathrm{MeOH}$ P.A., thus $\mathrm{MeOH}$ were employed as negative control. Whereas for the aqueous extract bioassay, distilled water was as negative control.

For the treatment application, engorged females were transferred to Petri dishes with the edges insulated with solid vaseline, to avoid escape. Then, the mites received $2 \mathrm{~mL}$ of each extract, by mean of airbrush coupled to an air compressor, under constant pressure of $0.84 \mathrm{Kgf} / \mathrm{cm}^{2}$ of exit. The volume of the solution for each experimental plot was $2 \mathrm{~mL}$. After spraying, the females were transferred to glass tubes closed with voile tissue . The mortality evaluation was performed after $24 \mathrm{~h}$, considering dead mites as those that did not present mobility to the touch with a brush. For the statistical analysis, the data were submitted to Kruskal-Wallis non-parametric test using $\mathrm{R} \otimes$ software ( $\mathrm{R}$ DEVELOPMENT CORE TEAM, 2017). 
RESULTS AND DISCUSSION

Phytochemical screening
Steroids, flavonoids, flavones, flavonols, saponins, tannins, triterpenoids and xanthones were detected (Table 1).

Table 1. Phytochemical prospection of aqueous and organic solvent extracts from leaves of Zanthoxylum caribaeum.

\begin{tabular}{lccccccc}
\hline \multirow{2}{*}{ Chemical compounds } & \multicolumn{7}{c}{ Extracting solvent } \\
\cline { 2 - 7 } & $\mathrm{AcO}$ & $\mathrm{AcOEt}$ & $\mathrm{EtOH}$ & $\mathrm{Hex}$ & $\mathrm{MeOH}$ & $\mathrm{CH}_{2} \mathrm{Cl}_{2}$ & $\mathrm{Aq}$ \\
\hline Alkaloids & - & - & - & - & - & - & - \\
Anthocyanidins & - & - & - & - & - & - & - \\
Anthocyanins & - & - & - & - & - & - & - \\
Aurones & - & - & - & - & - & - & - \\
Chalcones & - & - & - & - & - & - & - \\
Cumarines & - & - & - & - & - & - & - \\
Steroids & + & + & + & + & + & ++ & - \\
Flavanonols & - & - & - & - & - & - & + \\
Flavones & + & + & + & + & + & + & - \\
Flavonols & + & + & + & + & + & + & - \\
Saponins & - & - & - & - & - & - & + \\
Condensed tannins & - & - & + & - & ++ & - & + \\
Triterpenoids & + & + & + & + & + & + & + \\
Xanthones & + & + & + & + & + & + & + \\
\hline
\end{tabular}

${ }^{1}$ Acetone (AcO), ethyl acetate (AcOEt), ethanol (EtOH), hexane (Hex), methanol $(\mathrm{MeOH})$, dichloromethane $\left(\mathrm{CH}_{2} \mathrm{Cl}_{2}\right)$, and aqueous $(\mathrm{Aq}) ; 2(+)$ Positive reaction, $(++)$ strong positive reaction and $(-)$ negative reaction.

Except for the aqueous extract, all the others presented positive reaction $(+)$ for the presence of steroids (Table 1$)$. The strong positive reaction $(++)$ found for the soluble extract in $\mathrm{CH}_{2} \mathrm{Cl}_{2}$ is highlighted, this can be explained by the fact that steroids are apolar compounds. On the other hand, the aqueous extract was the only one that presented flavanonols, which are considered partially polar flavonoids and moderately soluble in polar solvents, such as water (BARAN, 1997 DIXON; PAIVA, 1995).

Flavones and flavonols have been detected in all organic solvents, independent of the polarity of the solvent, because although most flavonoids are moderately soluble in polar solvents, others tend to be more soluble in non-polar solvents such as ethers and chloroform (BARAN, 1997 DIXON; PAIVA, 1995). On the other hand, Saponins were found only in the aqueous extract. It is known that saponins have high polarity (MAJINDA, 2012). Also, because they were phenolic compounds, condensed tannins were detected when more polar solvents were used, such as ethanol, methanol and water (MELLO; SANTOS, 2001). The triterpenoids and xanthones were detected in all the extracts and did not present any difference in relation to the polarity.

The classes of secondary metabolites detected in $Z$. caribaeum leaves extracts, in the present work, are in agreement with the reported in the literature for other species of the same genus.
Phytochemical studies with Zanthoxylum spp. reported the presence of steroids, flavonoids, saponins, tannins, triterpenoids and xanthones (PAMHIDZAI; ISAAC, 2013; RAVIKUMAR et al.; 2012) which may be related to the biological activities found in the present work.

\section{Antimicrobial activity}

With the exception of the aqueous extract, all others promoted growth inhibition of Grampositive and Gram-negative bacteria, with the most pronounced results being found for soluble extracts in $\mathrm{EtOH}$ and $\mathrm{MeOH}$ (Table 2). This is because, they showed activity to practically all the microorganisms used in the bioassays.

In relation to gram-negative strains, soluble extracts in $\mathrm{MeOH}$ and $\mathrm{EtOH}$ showed moderate activity for $E$. coli, $S$. Enteritidis and $S$. Typhimurium, with MIC and MBC of $25 \mathrm{mg} \mathrm{mL}^{-1}$. The strains $P$. aeruginosa and $P$. mirabilis were more sensitive to the extract soluble in $\mathrm{MeOH}$, which presented high activity, with MIC and MBC of only $6.25 \mathrm{mg} \mathrm{mL}^{-1}$. For $K$. pneumoniae, the extract that showed the best activity was the soluble in EtOH, with MIC and MBC of $6.25 \mathrm{mg} \mathrm{mL}^{-1}$ (high activity). In relation to the Heidelberg and Newport serotypes, the extract that presented the best values of MIC and MBC was that soluble in AcOEt, whereas the Gallinarum serotype was more sensitive to the $\mathrm{AcO}$ extract. 
Table 2. Minimum Inhibitory Concentration (MIC), Minimum Bactericidal Concentration (MBC), Minimum Fungicidal Concentration (MFC) of aqueous and organic solvent extracts on leaves of Zanthoxylum caribaeum against different microbial strains.

\begin{tabular}{|c|c|c|c|c|c|c|}
\hline \multirow{3}{*}{$\begin{array}{l}\text { Microorganisms } \\
\text { Gram Negatives } \\
\end{array}$} & \multicolumn{6}{|c|}{ MIC / MBC-MFC $\left(\mathrm{mg} \mathrm{mL}^{-1}\right)^{1}$} \\
\hline & \multicolumn{6}{|c|}{ Extracting Solvent ${ }^{2}$} \\
\hline & $\mathrm{AcO}$ & $\mathrm{AcOEt}$ & EtOH & Hex & $\mathrm{MeOH}$ & $\mathrm{CH}_{2} \mathrm{Cl}_{2}$ \\
\hline $\begin{array}{l}\text { Proteus mirabilis } \\
\text { ATCC } 25933\end{array}$ & $50 / 50$ & $50 / 50$ & $12.5 / 12.5$ & $100 / 100$ & $6.25 / 6.25$ & $50 / 50$ \\
\hline $\begin{array}{c}\text { Klebsiella pneumoniae } \\
\text { ATCC } 13883\end{array}$ & $25 / 25$ & $25 / 25$ & $6.25 / 6.25$ & $50 / 50$ & $6.25 / 12.5$ & $25 / 25$ \\
\hline $\begin{array}{c}\text { Pseudomonas aeruginosa } \\
\text { ATCC } 27853\end{array}$ & $50 / 50$ & $50 / 50$ & $12.5 / 12.5$ & $100 / 100$ & $6.25 / 6.25$ & $50 / 50$ \\
\hline $\begin{array}{c}\text { Escherichia coli } \\
\text { ATCC } 25922\end{array}$ & $50 / 50$ & $50 / 50$ & $25 / 25$ & $100 / 100$ & $25 / 25$ & $25 / 50$ \\
\hline $\begin{array}{c}\text { Salmonella Enteritidis } \\
\text { ATCC } 13076\end{array}$ & $50 / 50$ & $25 / 50$ & $25 / 25$ & $100 / 100$ & $25 / 25$ & $50 / 50$ \\
\hline $\begin{array}{c}\text { Salmonella Typhimurium } \\
\text { ATCC } 14028\end{array}$ & $50 / 50$ & $25 / 50$ & $25 / 25$ & $100 / 100$ & $25 / 25$ & $50 / 50$ \\
\hline Salmonella Heidelberg* & $50 / 50$ & $25 / 25$ & $50 / 50$ & $100 / 200$ & $25 / 50$ & $200 / 200$ \\
\hline Salmonella Newport* & $50 / 50$ & $25 / 50$ & $50 / 50$ & $50 / 100$ & - & $200 / 200$ \\
\hline Salmonella Gallinarum* & $12.5 / 50$ & $25 / 50$ & $50 / 50$ & $100 / 100$ & $50 / 50$ & $100 / 200$ \\
\hline \multicolumn{7}{|l|}{ Gram Positives } \\
\hline $\begin{array}{l}\text { Bacillus subtilis } \\
\text { CCCD-B005 }\end{array}$ & $6.25 / 6.25$ & $3.12 / 3.12$ & $6.25 / 6.25$ & $\mathrm{Na}$ & $6.25 / 6.25$ & $0.78 / 0.78$ \\
\hline $\begin{array}{c}\text { Staphylococcus aureus } \\
\text { ATCC } 25923\end{array}$ & $25 / 50$ & $25 / 25$ & $12.5 / 12.5$ & $6.25 / 12.5$ & $6.25 / 12.5$ & $25 / 25$ \\
\hline $\begin{array}{c}\text { Staphylococcus epidermidis } \\
\text { ATCC } 12228\end{array}$ & $12.5 / 25$ & $25 / 25$ & $12.5 / 12.5$ & $25 / 25$ & $6.25 / 12.5$ & $6.25 / 25$ \\
\hline $\begin{array}{c}\text { Enterococcus faecalis } \\
\text { ATCC } 19433\end{array}$ & $50 / 50$ & $25 / 25$ & $25 / 50$ & $25 / 25$ & $25 / 50$ & $12,5 / 50$ \\
\hline \multicolumn{7}{|l|}{ Yeast } \\
\hline $\begin{array}{l}\text { Candida albicans } \\
\text { ATCC } 10231\end{array}$ & $50 / 50$ & $50 / 50$ & $25 / 25$ & $50 / 50$ & $25 / 25$ & $50 / 50$ \\
\hline
\end{tabular}

${ }^{1}(-)$ No activity; ${ }^{2}$ Acetone (AcO), ethyl acetate (AcOEt), ethanol (EtOH), hexane (Hex), methanol (MeOH) and dichloromethane $\left(\mathrm{CH}_{2} \mathrm{Cl}_{2}\right) ;$ * Salmonella enterica serotypes.

For the group of Gram-positive strains, $B$. subtilis was more susceptible to the $\mathrm{CH}_{2} \mathrm{Cl}_{2}$ extract, with MIC and MBC of $0.78 \mathrm{mg} \mathrm{mL}^{-1}$, the best value observed for antimicrobial activity among all microorganisms tested (high activity). The extracts soluble in $\mathrm{MeOH}$ and $\mathrm{Hex}$ were more effective against $S$. aureus, with MIC and MBC of 6.25 and $12.5 \mathrm{mg} \mathrm{mL}^{-1}$, respectively, indicating high activity of both extracts. The same was verified for the strain $S$. epidermidis, referring to the extract $\mathrm{MeOH}$. For the E. faecalis bacterium, all extracts presented almost the same efficacy, except for the $\mathrm{CH}_{2} \mathrm{Cl}_{2}$ extract that obtained the best inhibition, with a MIC value of $12.5 \mathrm{mg} \mathrm{mL}^{-1}$.

The standard yeast $C$. albicans was also sensitive to all extracts; soluble extracts in $\mathrm{EtOH}$ and $\mathrm{MeOH}$ showed moderate activity with $\mathrm{MIC}$ and MFC of $25 \mathrm{mg} \mathrm{mL}^{-1}$, followed by extracts soluble in
Hex, $\mathrm{AcO}, \mathrm{CH}_{2} \mathrm{Cl}_{2}$ and $\mathrm{AcOEt}$, with low activity, with MIC and MFC of $50 \mathrm{mg} \mathrm{mL}^{-1}$ and the aqueous extract showed no fungicidal activity.

The genus Zanthoxylum is a group of plants that presents as one of its characteristics bioactive compounds with antimicrobial activity. It is possible to exemplify the moderate activity of the aqueous extract of the leaves of Zanthoxylum capense (Thunb.) Harv. (Rutaceae) against B. subtilis, E. coli and $K$. pneumoniae, $S$. aureus, whereas the ethanolic extract presented high activity for $B$. subtilis, E. coli, $K$. pneumoniae and $S$. aureus (BUWA; STADEN, 2006). In the case of $Z$. capense, the acetone-soluble extract showed excellent activity against $S$. aureus, E. coli, E. faecalis and $P$. aeruginosa (ADAMU; VINNY; ELOF, 2014). Meanwhile, the ethanolic extract of Zanthoxylum chalybeum Engl. (Rutaceae) did not 
present an inhibitory action against E. coli, E. faecalis, $P$. aeruginosa and $S$. aureus, but demonstrated antifungal potential against $C$. albicans yeast (KUGLEROVA et al., 2011).

In relation to $Z$. caribauem, an antimicrobial action of soluble extracts in methanol, ethanol, acetone, ethyl acetate, dichloromethane, hexane and aqueous was observed against different Salmonella serotypes of poultry origin. However, as in our study, the aqueous extract did not obtain satisfactory results, demonstrating inhibition of growth only against the serotype $S$. enterica Mbandaka at the concentration of $200 \mathrm{mg} \mathrm{mL}^{-1}$ (SOUZA et al., 2017).

In general, it can be seen that both the $\mathrm{MeOH}$ extract and EtOH showed antimicrobial activity against most of the strains tested. This result may be justified by the fact that these extracts exhibit the presence of tannins, which are known to act on cell membranes and may alter permeability or even lead to the destruction of the cell (SCHENKEL et $\mathrm{al}, ; 2001)$. In bacteria, growth retardation has been associated with the formation of complexes between the tannins and the cell wall of secreted extracellular bacteria or enzymes, causing inhibition of nutrient transport into the cell (MCSWEENEY et al., 2001).

It is important to highlight that the use of solvents with different polarities in obtaining the extracts reflects the composition of the secondary metabolites found, which justify the differences regarding the antimicrobial activity of the extracts (MIGLIATO et al., 2011). With this, it was verified that the extracts with the solvent with greater polarity $(\mathrm{EtOH}$ and $\mathrm{MeOH})$ proved to be efficient in the antimicrobial action, in relation to the others.

The absence of the antimicrobial activity as in the aqueous extract of $Z$. caribaeum on different the microorganism may be related to the low concentrations of the potentially active substances, since the phytochemical screening allows us a qualitative and non-quantitative analysis of the secondary metabolites present (AYRES et al., 2008). In addition, since plant extracts are formed from complex mixtures, there may often be interactions between their constituents, which directly influence bioactivity (HEINRICH, 2010; JUNIO et al., 2011).

\section{Antioxidant activity}

It was observed that the extract soluble in EtOH obtained from the leaves of $Z$. caribaeum showed the highest percentage of free radical sequestration $(\mathrm{DPPH})(71.2 \%)$ and the lowest $\mathrm{IC}_{50}$ value $\left(24.39 \mu \mathrm{g} \mathrm{mL}^{-1}\right)$ when compared to the other extracts. Soluble extracts in $\mathrm{AcO}$ and $\mathrm{MeOH}$ also showed free radical sequestration above $50 \%$. The soluble extract in AcOEt had a free radical scavenger effect of $48.56 \%$, and these last three extracts had a moderate / intermediate percentage of antioxidant activity when compared to the commercial antioxidant BHT, with antioxidant activity of $92.80 \%$ and value of $\mathrm{IC}_{50}=7.93 \mu \mathrm{g} \mathrm{mL}$ (Table 3). While the soluble extracts $\mathrm{CH}_{2} \mathrm{Cl}_{2}$, Hex and $\mathrm{Aq}$ showed less than $10 \%$ sequestration, being considered without antioxidant activity.

Table 3. Antioxidant activity of aqueous and organic solvent extracts from the leaves of Zanthoxylum caribaeum by the DPPH method.

\begin{tabular}{cccc}
\hline & Test solution $^{1}$ & \% capture $\mathrm{DPPH}^{2}$ & $\mathrm{IC}_{50}\left(\mu \mathrm{g} \mathrm{mL}^{-1}\right)^{3}$ \\
\hline & $\mathrm{EtOH}$ & 71,12 & 24,39 \\
Extracting Solvent & $\mathrm{AcO}$ & 66,16 & 29,67 \\
& $\mathrm{MeOH}$ & 61,99 & 27,98 \\
& $\mathrm{AcOEt}$ & 48,56 & 29,67 \\
& $\mathrm{BHT}$ (positive control) & 92,80 & 7,93
\end{tabular}

${ }^{\mathrm{l}}$ Etanol $(\mathrm{EtOH})$, acetone $(\mathrm{AcO})$, methanol $(\mathrm{MeOH})$, ethyl acetate (AcOEt) and BHT (commercial synthetic antioxidant Butylhydroxytoluene); ${ }^{2}$ Percentage of radical sequestration DPPH (2,2-diphenyl-2-picrylhydrazyl); ${ }^{3}$ Concentration of $Z$. caribauem leaves extract is necessary to reduce $50 \%$ of the DPPH radical.

Although no studies have been found in the literature exploring the antioxidant activity of $Z$. caribaeum, Kuglerova et al. (2011) reported the antioxidant it' activity of $Z$. chalybeum Engl. (Rutaceae), which presented $\mathrm{IC}_{50}$ of $22.66 \mu \mathrm{g} \mathrm{mL}^{-1}$, whereas for the Trolox positive control, the $\mathrm{IC}_{50}$ was $3.49 \pm 0.19 \mu \mathrm{g} \mathrm{mL}^{-1}$. Likewise, the methanol and ethyl acetate soluble fractions of methanolic $Z$. rhetsa DC (Rutaceae) seeds exhibited expressive rapture activity compared to the ascorbic acid control with more than $50 \%$ free radical sequestration (PRABHASH; AGNEL, 2015).

The antioxidant compounds are very diverse, commonly found in plants, such as vitamins $\mathrm{C}$ and $\mathrm{E}$, carotenoids and phenolic compounds (OU et al., 2002). To Pérez-Jiménez and Saura-Calixto (2006) what can determine the extraction of these metabolites with antioxidant capacity is the type of 
solvent and its polarity, which are formed by the transfer of electrons from hydrogen atoms that give rise to compounds different antioxidants.

In the research of Xu and Chang (2007) it was verified that different solvents used in the extraction, resulted in different phenolic compositions and consequently differences in their antioxidants. In agreement with the authors above, it was recognized that extracts obtained through high polarity solvents, such as the soluble extract in $\mathrm{EtOH}$, are more effective as free radical scavengers and are considered to be good bacterial inhibitors when compared to those obtained from solvents of less polarity.

Therefore, the highest percentage of DPPH free radical sequestration of the EtOH-soluble extract in the present work is probably due to the antioxidant effect of phenolic compounds such as tannins and flavonoids, which are substances categorized as free radical scavengers, being very efficient in the prevention of autoxidation (SHAHIDI; JANITHA; WANASUNDARA, 1992).

\section{Acaricidal activity}

As for the Z. caribaeum extracts tested against the $D$. gallinae mite, the extract with the highest acaricidal activity was the soluble in $\mathrm{MeOH}$, with a maximum mortality of $37.6 \%$ at the concentration of $1000 \mathrm{mg} \mathrm{mL}^{-1}$, followed by the extract EtOH with $27.2 \%$ and $\mathrm{AcO}$ with $25.6 \%$. The other plant extracts presented very low toxicity for D. gallinae with values lower than 20\% (Table 4). The extracts obtained from $\mathrm{MeOH}$ and $\mathrm{EtOH}$ presented the highest values of mortality in comparison with the others, suggesting that their acaricide action is mainly related to the presence of steroids and condensed tannins, differing them from the other extracts tested.

Although the mortality caused by extracts has not been as pronounced, is possible suppose the existence toxic some metabolites for this mite in $Z$. caribauem (Table 4).

Table 4. Mortality from Dermanyssus gallinae treated with aqueous and organic solvent extracts from the leaves of Zanthoxylum caribaeum in different concentrations.

\begin{tabular}{|c|c|c|c|}
\hline Bioassays & Treatments $^{I}$ & Concentration $\left(\mathrm{mg} \mathrm{mL}^{-1}\right)$ & Mortality (\%) \\
\hline \multirow{17}{*}{ Bioassay 1} & Negative control & 0 & $0.8 \pm 0.80$ \\
\hline & \multirow{5}{*}{ Extract soluble in $\mathrm{MeOH}$} & 125 & $8.0 \pm 4.19$ \\
\hline & & 250 & $20.8 \pm 5.71$ \\
\hline & & 500 & $24.0 \pm 4.38$ \\
\hline & & 750 & $32.8 \pm 4.63^{*}$ \\
\hline & & 1000 & $37.6 \pm 4.11^{*}$ \\
\hline & \multirow{5}{*}{ Extract soluble in AcOEt } & 125 & $4.8 \pm 2.93$ \\
\hline & & 250 & $4.0 \pm 1.78$ \\
\hline & & 500 & $3.2 \pm 2.33$ \\
\hline & & 750 & $11.2 \pm 4.63$ \\
\hline & & 1000 & $5.6 \pm 0.97$ \\
\hline & \multirow{5}{*}{ Extract soluble in EtOH } & 125 & $5.6 \pm 3.70$ \\
\hline & & 250 & $10.4 \pm 2.71$ \\
\hline & & 500 & $24.8 \pm 5.85$ \\
\hline & & 750 & $29.6 \pm 6.14$ \\
\hline & & 1000 & $27.2 \pm 2.65$ \\
\hline & & \multicolumn{2}{|c|}{$\chi^{2}=54.5822 ; \mathrm{df}=15 ; \mathrm{p} \leq 0.001$} \\
\hline \multirow{11}{*}{ Bioassay 2} & Negative control & 0 & $1.6 \pm 0.97$ \\
\hline & \multirow{5}{*}{ Extract soluble in Hex } & 125 & $0.8 \pm 0.80$ \\
\hline & & 250 & $5.6 \pm 2.40$ \\
\hline & & 500 & $3.2 \pm 1.49$ \\
\hline & & 750 & $0.0 \pm 0.00$ \\
\hline & & 1000 & $6.4 \pm 1.60$ \\
\hline & \multirow{5}{*}{ Extract soluble in $\mathrm{AcO}$} & 125 & $0.8 \pm 0.80$ \\
\hline & & 250 & $4.0 \pm 1.26$ \\
\hline & & 500 & $8.0 \pm 3.09$ \\
\hline & & 750 & $24.8 \pm 5.27^{*}$ \\
\hline & & 1000 & $25.6 \pm 2.71^{*}$ \\
\hline
\end{tabular}




\begin{tabular}{|c|c|c|c|}
\hline & \multirow{5}{*}{ Extract soluble in $\mathrm{CH}_{2} \mathrm{Cl}_{2}$} & 125 & $6.4 \pm 3.70$ \\
\hline & & 250 & $0.8 \pm 0.80$ \\
\hline & & 500 & $2.4 \pm 1.60$ \\
\hline & & 750 & $1.6 \pm 1.60$ \\
\hline & & 1000 & $1.6 \pm 1.60$ \\
\hline & \multicolumn{3}{|c|}{$\chi^{2}=45.186 ; \mathrm{df}=15 ; \mathrm{p} \leq 0.001$} \\
\hline \multirow{6}{*}{ Bioassay 3} & Negative control & 0 & $0.0 \pm 0.00$ \\
\hline & \multirow{5}{*}{ Aqueous extract } & 125 & $3.2 \pm 2.33$ \\
\hline & & 250 & $4.8 \pm 2.93$ \\
\hline & & 500 & $8.0 \pm 1.78$ \\
\hline & & 750 & $4.8 \pm 1.49$ \\
\hline & & 1000 & $8.8 \pm 2.33$ \\
\hline
\end{tabular}

$\chi^{2}=8.4022 ; \mathrm{df}=5 ; \mathrm{p}=0.1354$

${ }^{\mathrm{I}}$ Methanol $(\mathrm{MeOH})$, ethyl acetate (EtOAc), ethanol (EtOH), hexane (Hex), acetone (AcO), dichloromethane $\left(\mathrm{CH}_{2} \mathrm{Cl}_{2}\right)$, and aqueous (Aq). *Means with statistical difference by non-parametric Kruskal-Wallis test $(p \leq 0.05)$.

The toxic activity of plant extracts of the genus Zanthoxylum against arthropods is well known, both to insect (MOUSSAVI et al., 2015) as larvae of the $R$. microplus tick (SANTOS et al., 2013). In relation to the species $Z$. caribauem, a high toxicity of the leaf essential oil on the $R$. microplus tick was reported, as mortality of $97 \%$ (NOGUEIRA et al., 2014a), however, this is the first study in which the toxicity of $Z$. caribaeum to the $D$. gallinae mite. So, phytochemical composition study is necessary and recommended.

\section{CONCLUSIONS}

The methanolic and ethanolic extracts were the most effective and with a broad spectrum of action against all tested microorganisms, including yeast $C$. albicans.

As for the antioxidant activity, the ethanolic extract proved to be a good free radical scavenger. Soluble extracts in methanol and acetone showed toxicity to the $D$. gallinae mite.

The phytochemical characterization evidenced the presence of steroids, flavanones, flavones, flavonols, saponins, tannins, triterpenoids and xanthones in the aqueous and organic solvent extracts of $Z$. caribauem leaves.

The results found in the present work show the biological potential of $Z$. caribaeum leaves extracts to obtain new bioactive substances.

RESUMO: A flora brasileira é conhecida pela sua vasta biodiversidade, no entanto, muitas espécies ainda são pouco estudadas quanto à composição química e ao potencial biológico. Assim, esse trabalho teve como objetivo determinar a atividade antimicrobiana, antioxidante e acaricida dos extratos vegetais das folhas de Zanthoxylum caribaeum L. Adicionalmente, foi realizada triagem fotoquímica desses extratos para determinar as principais classes de metabólitos secundários presentes em Z. caribaeum. Empregando-se as folhas de $Z$. caribaeum foram obtidos o extrato aquoso e orgânicos, utilizando os seguintes solventes (etanol, metanol, hexano, acetona, diclorometano e acetato de etila). A atividade antimicrobiana dos extratos foi determinada pelo método de microdiluição em caldo, e para detecção da atividade antioxidante foi empregado o método de captura do radical livre 2,2-difenil-1-picril hidrazil (DPPH). A atividade acaricida dos extratos foi avaliada frente a Dermanyssus gallinae (De Geer) (Acari: Dermanissidae). Os extratos brutos etanólico e metanólico apresentaram atividade antimicrobiana para a maioria das cepas bacterianas testadas, e também para a levedura Candida albicans. O extrato etanólico apresentou elevado potencial de sequestro de radicais livres $(71,2 \%)$ e o menor valor de $\mathrm{IC}_{50}\left(24,39 \mu \mathrm{g} \mathrm{mL}^{-1}\right)$, revelando, portanto, sua capacidade antioxidante. No que se refere à atividade acaricida, os extratos obtidos com metanol e acetona foram os mais promissores. De modo geral, a triagem fitoquímica indicou a presença de esteroides, flavanonas, flavonas, flavonóis, saponinas, taninos, triterpenóides e xantonas.

PALAVRAS-CHAVE: Atividade antimicrobiana. Atividade antioxidante. Atividade acaricida. Ácaro vermelho das galinhas. Salmonella enterica. 


\section{REFERENCES}

ADAMSKA-SZEWCZYK, A.; GLOWNIAK, K.; BAJ, T. Furochinoline alkaloids in plants from Rutaceae family-a review. Current Issues in Pharmacy and Medical Sciences, v. 29, n. 1, p. 33-38, 2016. https://doi.org/ 10.1515/cipms-2016-0008

ADAMU, M.; VINNY, N.; ELOF, J. N. The antibacterial activity, antioxidant activity and selectivity index of leaf extracts of thirteen South African tree species used in ethnoveterinary medicine to treat helminth infections. BMC veterinary research, v. 10, n. 1, p. 52, 2014. https://doi.org/10.1186/1746-6148-10-52

AYRES, M. C.; BRANDÃO, M. S.; VIEIRA-JÚNIOR, G. M.; MENOR, J. C. A. S.; SILVA, H. B.; SOARES, M. J. S.; CHAVES, M. H.. Atividade antibacteriana de plantas úteis e constituintes químicos da raiz de Copernicia prunifera. Revista Brasileira de Farmacognosia, v. 18, n. 1, p. 90-7, 2008. https://doi.org/10.1590/S0102-695X2008000100017

BAJ, T.; KUKULA-KOCH, W.; ŚWIĄTEK, Ł.; ZIELIŃSKA-PISKLAK; M., ADAMSKA-SZEWCZYK, A.; SZYMCZYK, D.; RAJTAR, B.; POLZ-DACEWICZ, m.; SKALICKA-WOŹNIAK, K.. Chemical profile, antioxidant activity and cytotoxic effect of extract from leaves of Erythrochiton brasiliensis Nees \& Mart. from different regions of Europe. Open Chemistry, v. 15, n. 1, p. 380-388, 2017. https://doi.org/10.1515/chem2017-0042

BARAN, R. . Changes in phenolic compounds and colour in pole cherry wines subjected to fining treatment. Zeitschrift Fur Lebensmittel-Untersuchung Und - Forschung, v. 205, n. 6, p. 474-478, 1997. https://doi.org/10.1007/s002170050202

BUWA, L. V.; STADEN, V. J. Antibacterial and antifungal activity of traditional medicinal plants used against venereal diseases in South Africa. Journal of Ethnopharmacology, v. 103, n. 1, p. 139-142, 2006. https://doi.org/10.1016/j.jep.2005.09.020

COSTA, J. F. O.; JUIZ, P., SÃO PEDRO, A.; DAVID, J. P. D. L.; DAVID, J. M.; GIULIETTI, A. M.; FRANÇA, F.; SANTOS, R. R.; SOARES, M. B. . Immunomodulatory and antibacterial activities of extracts from Rutaceae species. Revista Brasileira de Farmacognosia, v. 20, n. 4, p. 502-505, 2010. http://dx.doi.org/10.1590/S0102-695X2010000400007

DIXON, S. A;PAIVA, N. L. Stress induced phenylpropanoid metabolism. Plant Cell, v. 7, n. 7, p. 1085, 1995. https://doi.org/10.2307/3870059

FERRAZ, J. C. B.; MATOS, C. H. C.; OLIVEIRA, C. R. F. D.; SÁ, M. D. G. R. D.; CONCEIÇÃO, A. G. C. D. Acaricidal activity of juazeiro leaf extract against red spider mite in cotton plants. Pesquisa Agropecuária Brasileira, v. 52, n. 7, p. 493-499, 2017. http://dx.doi.org/10.1590/s0100-204x2017000700003

FERREIRA, M. E.; NAKAYAMA, H.; DE ARIAS, A. R.; SCHININI, A.; DE BILBAO, N. V.; SERNA, E.; LAGOUTTE, D. ; SORIANO-AGATON, F.; POUPON, E.; HOCQUEMILLER, R.; FOURNET, A.. Effects of canthin-6-one alkaloids from Zanthoxylum chiloperone on Trypanosoma cruzi-infected mice. Journal of Ethnopharmacology, v. 109, n. 2, p. 258-263, 2007. doi:10.1016/j.jep.2006.07.028

FLECHTMANN, C. H. W. Ácaros de importância medico-veterinária. São Paulo: Nobel; 1985. 192p.

GREGER, H. Phytocarbazoles: alkaloids with great structural diversity and pronounced biological activities.Phytochemistry Reviews, v. 16, n. 6, p. 1095-1153, 2017. 10.1007/s11101-017-9521-5

HEINRICH, M. Ethnopharmacology and drug discovery. In: LIU, H. W.; MANDER, L. (Eds.)

Comprehensive Natural Products II: Chemistry and Biology, Amsterdam: Elsevier, 2010, p.351-381. 
JUNIO, H. A.; SY-CORDERO, A. A.; ETTEFAGH, K. A.; BURNS, J. T.; MICKO, K. T.; GRAF, T. N.; RICHTER, S. J.; CANNON, R. E.; OBERLIES, N. H.; CECH, N. B. . Synergy-directed fractionation of botanical medicines: a case study with goldenseal (Hydrastis canadensis). Journal of Natural Products, v. 74, n. 7, p. 1621-1629, 2011. 10.1021/np200336g

KUGLEROVA, M.; TESAROVA, H.; GRADE, J. T.; HALAMOVA, K.; WANYANA-MAGANYI, O.; VAN DAMME, P.; KOKOSKA, L. Antimicrobial and antioxidative effects of Ugandan medicinal barks. African Journal of Biotechnology, v. 10, n. 18, p. 3628-3632, 2011. 10.5897/AJB09.1815

LV, M.; XU, P.; TIAN, Y.; LIANG, J.; GAO, Y.; XU, F.; ZHANG, Z.; SUN, J.. Medicinal uses, phytochemistry and pharmacology of the genus Dictamnus (Rutaceae). Journal of Ethnopharmacology, v. 171, p. 247-263, 2015. doi: 10.1016 / j.jep.2015.05.053

MAJINDA, R. R. T. Extraction and isolation of saponins. In: SARKER S., NAHAR L. (Eds.) Natural Products Isolation (Methods in Molecular Biology series), Mumbai: Springer Science, 2012, v. 864, p. 415426. https://doi.org/10.1007/978-1-61779-624-1_16

MATOS, F. J. A. Introdução a fitoquímica experimental. 2.ed. Fortaleza: Edições UFC, 1997. 141 p.

McSWEENEY, C. S. ;PALMER, B.; BUNCH, R.; KRAUSE, D.O. Effect of the tropical forage calliandra on microbial protein synthesis and ecology in the rumen. Journal of Applied Microbiology, v. 90, n. 1, p. 78-88, 2001. 10.1046/j.1365-2672.2001.01220.x

MELLO, J. P. C.; SANTOS, S. C. Em Farmacognosia: da planta ao medicamento; Simões, C. M. O.; Schenckel, E. P., orgs.; Ed. UFSC: Porto Alegre; $3^{\text {a }}$ ed., 2001.

MIGLIATO, K. F.; CORRÊA, M. A.; SALGADO, H. R. N.; TOGNOLLI, J. O.; SACRAMENTO, L. V. S.; MELLO, J. C. P. D.; GIANNINI, M. J. S. M.; ALMEIDA, A. M. F.; PIZZOLITTO, A. C. Planejamento experimental na otimização da extração dos frutos de Syzygium cumini (L.) skeels. Química Nova, p. 695-699, 2011. https://doi.org/10.1590/S0100-40422011000400024

MOUSSAVI, N.; MALTERUD, K. E.; MIKOLO, B.; DAWES, D.; CHANDRE, F.; CORBEL, V.; MASSAMBA, D.; OVERGAARD, H. J.; WANGENSTEEN, H.. Identification of chemical constituents of Zanthoxylum heitzii stem bark and their insecticidal activity against the malaria mosquito Anopheles gambiae. Parasites \& Vectors, v. 8, n. 1, p. 503, 2015. https://doi.org/10.1186/s13071-015-1113-x

MÜGGE, F. L.; PAULA-SOUZA, J.; MELO, J. C.; BRANDÃO, M. G.. Native plant species with economic value from Minas Gerais and Goiás: a discussion on the currentness of the data recovered by the French naturalist Auguste de Saint-Hilaire. Horticultura Brasileira, v. 34, n. 4, p. 455-462, 2016. http://dx.doi.org/10.1590/S0102-053620160402

NOGUEIRA, J.; VINTURELLE, R.; MATTOS, C.; TIETBOHL, L. A. C.; SANTOS, M. G.; DA SILVA VAZ, I.; MOURA, S. C.; ROCHA, L.; FOLLY, E.. Acaricidal properties of the essential oil from Zanthoxylum caribaeum against Rhipicephalus microplus. Journal of Medical Entomology, v. 51, n. 5, p. 971-975, 2014a. https://doi.org/10.1603/ME13236

NOGUEIRA, J.; MOURÃO, S. C.; DOLABELA, I. B.; SANTOS, M. G.; MELLO, C. B.; KELECOM, A.; MEXAS, R.; FEDER, D.; FERNANDES, C. P.; GONZALEZ, M. S.; ROCHA, L.. Zanthoxylum caribaeum (Rutaceae) essential oil: Chemical investigation and biological effects on Rhodnius prolixus nymph.

Parasitology Research, v. 113, n. 11, p. 4271-4279, 2014b. https://doi.org/10.1007/s00436-014-4105-4

ORDAZ PICHARDO, C.; CLEMENTE GARCÉS, R.; LÓPEZ VILLAFRANCO, M.; GARZA, M. D. L.; ARRIAGA-ALBA, M. Mutagenicity study and antibacterial activity of Erythrina herbácea, Zanthoxylum caribaeum and Dendropanax arboreus. Revista Mexicana de Ciencias Farmaceuticas, v. 45, n. 1, p. 78-85, 2014. 
OU, B.; HUANG, D.; HAMPSCH-WOODILL, M.; FLANAGAN, J. A.; DEEMER, E. K. Analisys of antioxidant activities of common vegetables employing oxygen radical absorbance capacity (ORAC) and ferric reducing antioxidant power (FRAP) assays: a comparative study. Journal of Agricultural and Food Chemistry, v. 50, n. 11, p. 3122-3128, 2002. 10.1021/jf0116606

PALMQUIST, K.; SALATAS, J.; FAIRBROTHER, A. Pyrethroid insecticides: use, environmental fate, and ecotoxicology. In: PERVEEN, F. Insecticides - advances in integrated pest management. New York: InTech, 2012, p.251-278. https://doi.org/10.5772/29495

PAMHIDZAI, D.; ISAAC, G. TLC separation, antibacterial and anti-inflammatory activity of extracts derived from Zanthoxylum humile roots. International Journal of Research in Ayurveda and Pharmacy, v. 4, n. 4, 2013. 10.7897 / 2277-4343.04403

PANDINI, J. A.; PINTO, F. G. S.; SCUR, M. C.; ALVES, L. F. A.; MARTINS, C. C. Antimicrobial, insecticidal, and antioxidant activity of essential oil and extracts of Guarea kunthiana A. Juss. Journal of Medicinal Plant Research, v. 9, n. 3, p. 48-55, 2015. 10.7897 / 2277-4343.04403

https://doi.org/10.5897/JMPR2014.5551

PEREIRA, J. A. R.; TEIXEIRA, M. C.; SACZK, A. A.; BARCELOS, M. D. F. P.; OLIVEIRA, M. F. D.; ABREU, W. C. D. Total antioxidant activity of yacon tubers cultivated in Brazil. Ciência e Agrotecnologia, v. 40, n. 5, p. 596-605, 2016. http://dx.doi.org/10.1590/1413-70542016405009416

PÉREZ-JIMÉNEZ, J.; SAURA-CALIXTO, F. Effect of solvent and certain food constituents on different antioxidant capacity assays. Food Research International, v. 39, n. 7, p. 791-800, 2006.

https://doi.org/10.1016/j.foodres.2006.02.003

PIRANI, J. R. Zanthoxylum in Lista de Espécies da Flora do Brasil. Jardim Botânico do Rio de Janeiro, 2015. Available in: <http://floradobrasil.jbrj.gov.br/jabot/floradobrasil/FB1064>. Access in: February, 03, 2018.

PRABHASH, T.; AGNEL N. A. J. Antioxidant and phytochemical analysis of Zanthoxylum rhetsa (Roxb) seed extract. International Journal of Current Research, v. 4, n. 1, p. 18-22, 2015.

R Development Core Team. R: a language and environment for statistical. Vienna, 2017. Available in: $<$ http://www.R-project.org>. Access in: July 01, 2018.

RATES, S. M. K. Plants as source of drugs. Toxicon, v. 39, n. 5, p. 603-613, 2001. https://doi.org/10.1016/S0041-0101(00)00154-9

RAVIKUMAR, V. R.; GOPAL, V.; SUDHA, T. Analysis of phytochemical constituents of stem bark extracts of Zanthoxylum tetraspermum wight \& Arn. Research Journal of Pharmaceutical, Biological and Chemical Sciences, v. 3, n. 4, p. 391-402, 2012.

SANTI, I. I.; GATTO, D. A.; MACHADO, M. R. G.; SANTOS, P. S. B.; FREITAG, R. A. Chemical Composition, Antioxidant and Antimicrobial Activity of the Oil and Plant Extract Myrocarpus frondosus Allemão. American Journal of Plant Sciences, v. 8, n. 07, p. 1560, 2017. 10.4236/ajps.2017.87108

SANTOS, L. B. D.; SOUZA, J. K.; PAPASSONI, B.; BORGES, D. G. L.; JUNIOR, G. A. D.; SOUZA, J. M. E. D.; DAMASCENO JUNIOR, G. A.; SOUZA, J. M. E.; CAROLLO, C. A.; BORGES, F. D. A.. Efficacy of extracts from plants of the Brazilian Pantanal against Rhipicephalus (Boophilus) microplus. Revista Brasileira de Parasitologia veterinária, v. 22, n. 4, p. 532-538, 2013. http://dx.doi.org/10.1590/S198429612013000400013

SCHENKEL, E. P.; GOSMANN, G.; ATHAYDE, M.L. Saponinas. In: SIMÕES, C.M.; SCHENKEL, E. P.; GOSMANN, G.; MELLO, J. C.P.; MENTZ, L.A.; PETROVICK, P. R. Farmacognosia: da planta ao medicamento. Porto Alegre/Florianopolis: Ed. UFGRS/Ed. UFSC, 2001. p.597-619. 
SCHNEE, L. Plantas comunes de Venezuela. Caracas: Universidad Central de Venezuela (UCV), 1984. 806p.

SCUR, M. C.; PINTO, F. G. S.; BONA, E. A. M.; WEBER, L. D.; ALVES, L. F. A.; MOURA, A. C. Occurrence and antimicrobial resistance of Salmonella serotypes isolates recovered from poultry of Western Paraná, Brazil. African Journal of Agricultural Research, v. 9, n. 9, p. 823-830, 2014.

10.5897/AJAR2013.8202

SHAHIDI, F.; JANITHA, P. K.; WANASUNDARA, P. D. Phenolic antioxidants. Critical Reviews in Food Science and Nutrition, v. 32, n. 1, p. 67-103, 1992. https://doi.org/10.1080/10408399209527581

SILVA, R. P. D.; MACHADO, B. A. S.; DE ABREU BARRETO, G.; COSTA, S. S.;ANDRADE, L. N.; AMARAL, R. G.; CARVALHO, A. A.; PADILHA, F. F.; , BARBOSA, J. D. V. B.; UMSZA-GUEZ, M. A. Antioxidant, antimicrobial, antiparasitic, and cytotoxic properties of various Brazilian propolis extracts. PLoS ONE, v. 12, n. 3, p. e0172585, 2017. https://doi.org/10.1371/journal.pone.0172585

SOUZA, J. G. L.; TOLEDO, A. G.; SANTANA, C. B.; SANTOS, C. V. D.; MALLMANN, A. P.; SILVA, J. P. B.; PINTO, F. G. S. Chemical composition and antibacterial activity of essential oil and leaf extracts of Zanthoxylum caribaeum Lam. against serotypes of Salmonella. Revista Brasileira de saúde e produção e animal, v. 18, n. 3, p. 446-453, 2017. http://dx.doi.org/10.1590/S1519-99402017000300005

SUPABPHOL, R.; TANGJITJAREONKUN, J. Chemical constituents and biological activities of Zanthoxylum limonella (Rutaceae): A review. Tropical Journal of Pharmaceutical Research, v. 13, n. 12, p. 2119-2130, 2014. http://dx.doi.org/10.4314/tjpr.v13i12.25

TUNDIS, R.; LOIZZO, M. R.; MENICHINI, F. An Overview on Chemical Aspects and Potential Health Benefits of Limonoids and Their Derivatives. Critical Reviews in Food Science and Nutrition, v. 54, n. 2, p. 225-250, 2014. 10.1080/10408398.2011.581400.

WEBER, L. D.; PINTO, F. G. S.; SCUR, M. C.; SOUZA, J. G. L.; COSTA, W. F.; LEITE, C. W. Chemical composition and antimicrobial and antioxidant activity of essential oil and various plant extracts from Prunus myrtifolia (L.) Urb. African Journal of Agricultural Research, v. 9, n. 9, p. 846-853, 2014.

10.5897/AJAR2013.8260

XU, B. J.; CHANG, S. K. C. Sensory \& Nutritive Qualities of Food: A comparative Study on Phenolic Profiles and Antioxidant Activities of Legumes as Affected by Extraction Solventes. Journal of Food Science, v. 72, n. 2, p. S159-S166, 2007. 10.1111 / j.1750-3841.2006.00260.x

ZHANG, M.; WANG, J.; ZHU, L.; LI, T.; JIANG, W.; ZHOU, J.; PENG, W.; WU, C. Zanthoxylum bungeanum Maxim. (Rutaceae): A systematic review of its traditional uses, botany, phytochemistry, pharmacology, pharmacokinetics, and toxicology. International Journal of Molecular Sciences, v. 18, n. 10, p. 2172, 2017. $10.3390 /$ ijms 18102172. 